УДК 339.15.2

\title{
ЛОГІСТИЧНЕ УПРАВЛІННЯ ПІДПРИЕМСТВОМ В УМОВАХ РИНКОВОЇ ЕКОНОМІКИ
}

\author{
Товма Л.Ф., к.т.н., доцент (НА НГУ), капіман
}

\begin{abstract}
Розкрито основні наукові підходи до визначення сутності логістичного управління підприємством, обтрунтовано мету і принципи логістичного управління. Проаналізовано основні причини, щуо зумовлюють труднощі імплементації основних положень логістики на вітчизняних підприємствах. Зазначено, що логістичне управління здійснюється на основі загальних принципів управління з урахуванням специффіки логістичної діяльності підприємства. Розкрито, щзо ефективна діяльність підприємства неможлива без упровадження інформаційної системи управління.
\end{abstract}

Ключові слова: логістичне управління, логістичний підхід, логістична система, матеріальні потоки, інформаційна логістична система.

\section{ЛОГИСТИЧЕСКОЕ УПРАВЛЕНИЯ ПРЕДПРИЯТИЕМ В УСЛОВИЯХ РЫНОЧНОЙ ЭКОНОМИКИ}

\author{
Товма Л.Ф., к.т.н., доцент (НА НГУ), капитан
}

Раскрыты основные научные подходы к определению сущности логистического управления предприятием, обоснованно цели и принципы логистического управления. Проанализированы основные причины, обусловливающие трудности имплементации основных положений логистики на отечественных предприятиях. Отмечено, что логистическое управление осуществляется на основе общих принцииов управления с учетом спеиифики логистической деятельности предприятия. Раскрыто, что эффективная деятельность предприятия невозможна без внедрения информационной системь управления.

Ключевые слова: логистическое управление, логистический подход, логистическая система, материальные потоки, информационная логистическая система.

\section{LOGISTIC MANAGEMENT OF THE ENTERPRISE IN THE CONDITIONS OF THE MARKET ECONOMY}

\author{
Tovma L.F., Candidate of Technical Sciences, Associate Professor \\ (National Guard of Ukraine), Captain
}

The main preconditions for the entry of Ukraine's economy into the sphere of logistics are its specificity, which is conditioned by the temporary factors associated with the transitional character of the Ukrainian economic system, as well as with longer and more permanent factors, in particular, such as the size and geographic location of the country; types, volumes, quality and availability of natural resources; availability of intellectual potential and skilled labor resources; size, specialization and distribution of production complexes and centers on the territory of the country; level of integration into the world economic space.

(C) Товма Л.Ф.

Вісник економіки транспорту і промисловості № 62, 2018 
Despite the multifaceted and breadth of logistic management goals, logistic scientists highlight the common goals inherent in all logistics system participants. The main among them are: improvement of processes of physical movement of resources and finished products in all the structures covered by logistics management; Harmonization of strategic, tactical and operational logistics goals with the general goals and strategies of enterprises or other participants in the logistics chain; direction of the integrated activity of logistics chain participants on effective customer service on the principle of "high value - allowable costs".

Characteristic for the logistic concept of thinking by system categories requires the interpretation of logistic tasks as a complex of dependencies, and logistics - as the only enclosed in it space tasks of the enterprise. In the theory of enterprise management, such a sphere of tasks is defined as an important function of the enterprise.

Effective enterprise activity is impossible without the introduction of an information management system, the availability of which allows faster response to changes in the market, streamline the management process, automate the implementation of a number of operations.

Key words: logistic management, logistic approach, logistic system, material flows, information logistic system.

Постановка проблеми та їі зв'язки 3 науковими чи практичними завданнями. У сучасних умовах розвитку ринкової економіки виникає потреба досягнення підприємством стабільності на ринку та закріплення його позицій серед конкурентів. Вирішення цієї проблеми пов'язане із формуванням власної ринкової стратегіï, проведенням постійних маркетингових досліджень, моніторингу мікро- i макросередовища фірми та виробленням певної моделі поведінки, що дасть змогу розвиватись та освоювати нові ринкові сегменти. Проведення в Україні економічних реформ багато вчених i практиків пов'язують 3 можливістю використання на всіх рівнях управління класичних інструментів менеджменту, маркетингу, логістики. Однак, як показав досвід реформування вітчизняної економіки, ці інструменти добре зарекомендували себе в стабільній економіці розвинених країн, не завжди і не скрізь успішно застосовуються у вітчизняних реаліях. Це стосується насамперед логістики, яка, на відміну від менеджменту та маркетингу, до сьогодні не має чіткого концептуального бачення для іiі ефективного використання.

Аналіз останніх досліджень i публікацій та виділення невирішених частин загальної проблеми. Значення логістики для досягнення цілей підприємства досліджувалося в роботах [1, 2]. Проблеми розвитку логістики під час формування ринкової економіки розглядалися в працях [3, 4]. Особливості застосування логістики в умовах функціонування розвиненої економіки знайшли свого відображення в роботі [5]. Проте зазначені літературні джерела не містять систематизованої інформації стосовно логістичного управління підприємством в умовах ринкової економіки.

Отже метою роботи є дослідження питань щодо сутності логістичного управління підприємством в умовах ринкової економіки.

Виклад основного матеріалу дослідження. Незважаючи на те, що застосування логістики в економіці України зумовлене сучасними реаліями, управлінню підприємствами на засадах логістичних підходів приділяється поки що недостатньо уваги порівняно із розвиненими країнами. Зарубіжні компанії давно й успішно використовують логістичні підходи, тоді як українські підприємці роблять тільки перші кроки в цьому напрямі.

Труднощі імплементації основних положень логістики на вітчизняних підприємствах полягають, насамперед, у 
нестабільності економіки України, а найважливіші проблеми, пов'язані 3 ефективним використанням логістики у вітчизняному підприємництві, на думку науковців [2, 3], можна поділити на об'єктивні й суб'єктивні [6]

Об'єктивними причинами $\epsilon$ недосконалість методологічної бази впровадження логістики в реальний сектор економіки України; невизначеність меж використання логістики в існуючих господарських системах; нестійке правове поле діяльності підприємницьких структур, a також непродумана система оподаткування; відсутність необхідної структуризації діяльності господарських систем, яка потрібна для впровадження логістики; значний моральний і фізичний знос виробничого устаткування; слаборозвинена транспортна інфраструктура, яка не відповідає сучасним вимогам (високий ступінь фізичного i морального зносу транспортних засобів i, як наслідок, низька ефективність їх функціонування); низький рівень розвитку виробничо-технічної бази складського господарства; недостатній рівень розвитку й використання сучасних систем електронних комунікацій, електронних мереж, систем зв'язку та телекомунікацій.

Суб'єктивними причинами $є$ відсутність кваліфікованих фахівців 3 логістики i потенційне небажання менеджерів змінювати сталі стереотипи роботи на тлі загальної низької правової й управлінської культури. Начальники служб постачання, доставки, продажів, які звикли виконувати свої традиційні функції, перешкоджають упровадженню наскрізної схеми управління матеріальними потоками підприємства, оскільки цілі логістики не збігаються 3 цілями окремих функціональних підрозділів. Більше того, окреме підприємство, оптимізоване 3 погляду логістики, може виявитися неоптимальною ланкою в загальному логістичному ланцюзі зв'язку з тим, що логістичний підхід передбачає включення в ланцюг безпосередньо виробничого підприємства i пов'язаних 3 ним постачальників, посередників, клієнтів. Саме координація роботи ланцюга, що складається 3 різних підприємств, $\epsilon$ найважчою при використанні логістичних методів управління.

Основні передумови входження економіки України у сферу логістичного управління мають свою специфіку, зумовлену як тимчасово діючими факторами, пов'язаними 3 перехідним характером української системи господарювання, так і з більш тривалими та постійно діючими факторами, зокрема такими, як розміри i географічне розташування країни; види, обсяги, якість і доступність природних ресурсів; наявність інтелектуального потенціалу i кваліфікованих трудових ресурсів; розміри, спеціалізація і розподіл по території країни виробничих комплексів і центрів; рівень інтеграції у світовий економічний простір [4].

Не зважаючи на багатоаспектність $\mathrm{i}$ широту цілей логістичного управління, науковці-логісти [5] виділяють спільні цілі, властиві всім учасникам логістичних систем. Головними серед них вважаються: удосконалення процесів фізичного переміщення ресурсів і готової продукції в усіх структурах, охоплених логістичним управлінням; гармонізація стратегічних, тактичних і оперативних логістичних цілей iз загальними цілями i стратегіями підприємств або інших учасників логістичного ланцюга; спрямування інтегрованої діяльності учасників логістичного ланцюга на ефективне обслуговування клієнта за принципом “висока користь - допустимі витрати”.

Логістичний підхід до управління підприємством націлений на забезпечення раціоналізації потокових процесів у рамках керованої системи 3 позиції єдиного матеріалопровідного ланцюга, інтеграція окремих частин якого здійснюється на технічному, технологічному, економічному, методологічному рівнях, а мінімізація витрат часу $\mathrm{i}$ ресурсів 
досягається шляхом оптимізації наскрізного управління матеріальними, інформаційними та фінансовими потоками. Таким чином, логістичне управління полягає в цілеспрямованому впливі на логістичні потоки 3 метою синхронізації їхньої взаємодії i досягнення ефекту синергізму.

Як головна підсистема загальної системи управління підприємством логістичне управління спрямоване на досягнення стратегічних і тактичних цілей розвитку підприємства. Логістичне управління інвестиційною, інноваційною, виробничою, фінансовою, кадровою та інформаційною сферами діяльності сприяє реалізації стратегічних, а всіма потоковими процесами в ланцюзі «закупівля ресурсів транспортування - виробництво складування - реалізація - сервісне обслуговування кінцевих споживачів» тактичних цілей підприємства.

Загальною метою логістичного управління $є$ реалізація й узгодження економічних інтересів безпосередніх i опосередкованих

підприємницьких процесів через найефективніше використання ресурсів в існуючих на даний час умовах господарювання. Загальна мета діяльності кожного підприємства конкретизується у підцілях, які визначаються потребами оптимізації і раціоналізації підприємницької діяльності, розвитком інфраструктури логістичної системи 3 урахуванням чинного законодавства про створення сучасної матеріально-технічної бази виробництва i товарного обміну, активного використання прогресивних інформаційних технологій.

Діяльність будь-якого підприємства можна охарактеризувати як процес, що постійно повторюється, тому логістичне управління можна розглядати як замкнений управлінський цикл, який також постійно повторюється. Як циклічний процес логістичне управління розглядають 3 позицій структурного, процесного та функціонального підходів, які тісно пов'язані між собою.

Діяльність промислового

підприємства як логістичної системи, тобто такої, що підлягає логістичному

управлінню, може бути подана за фазовим поділом трьома блоками [1]:

- логістика постачання, під якою розуміють комплексне планування, управління та фізичне опрацювання потоку матеріалів, сировини, комплектуючих та відповідного інформаційного потоку від їх переміщення від постачальників до початкового виробничого складування;

- логістика виробництва, яка включає управління процесами від початку виробництва до передавання продукції у сферу збуту;

- логістика збуту охоплює управління переміщенням готових виробів до замовника. Відмінною рисою логістичного управління $€$ системний, цілісний підхід до організації та здійснення переміщень матеріалів і готових виробів на всьому шляху від виготовлення до кінцевого споживання. Логістичний підхід надає можливість розглядати рух вантажу від постачальника до споживача як систему, що становить поєднання взаємодіючих логістичних ланцюгів.

Характерне для логістичної концепції мислення системними категоріями вимагає трактування логістичних завдань як комплексу залежностей, а логістики - як єдиного замкненого в собі простору завдань підприємства. У теорії управління підприємством така сфера завдань визначається як важлива функція підприємства. Тобто логістика трактується як одна 3 важливих функцій, які реалізуються на підприємстві, серед яких можна виділити основні й допоміжні [7]. Якщо трактувати функції досліджень i розвитку, постачання, виробництва i збуту, які випливають безпосередньо 3 ринкових завдань як “основні функціi”, підприємства, то “допоміжними функціями”, окрім 
логістичної, можна вважати ті функції, які стосуються персоналу, фінансів та інформації. Допоміжний характер цих функцій не означає другорядності їх ролі щодо основних функцій, а вказує на взаємозв'язок $з$ останніми. Яка 3 функцій має більше значення для ефективності діяльності підприємства, залежить від існуючої ситуації у сфері конкуренції i витрат.

Досвід провідних зарубіжних країн доводить високу ефективність логістики в отриманні стійких конкурентних переваг. Завдяки їй підприємства забезпечують необхідний рівень обслуговування кінцевого споживача, надаючи йому при цьому певні додаткові користі (цінності). Ці додаткові цінності можуть стосуватися і еластичності поставок щодо величини партії, і еластичності щодо умов оплати, i еластичності щодо термінів та місця виконання замовлення. Пов'язуючи викладене із характеристикою концепції логістики, зупинимося детальніше на сутності найбільш важливих логістичних складових конкурентоспроможності підприємства, серед яких можна назвати наступні: - елімінація часу логістичних операцій; - підвищення якості надання послуг; - зниження логістичних витрат.

Елімінація часу виконання логістичних операцій полягає $\mathrm{y}$ використанні методу цілісності часу виробництва. Науковці по-різному трактують сутність цього методу. Й. Монден описує так: «Метод цілісності часу виробництва - це виробництво продукції в необхідній кількості у необхідний час за мінімальний проміжок часу». Р. Халл, визначаючи цей метод як філософію виробництва, зазначає: «це транспортування і доставка матеріалів 3 метою постачання необхідних ресурсів та матеріалів у певний час у певному місці». Таким чином метод цілісності часу виробництва містить весь процес виробництва 3 постачанням необхідної кількості ресурсів та матеріалів у певний час. Використання методу скорочення часу логістичних операцій дає можливість підприємству гнучко реагувати на зміни у ринковому середовищі. Тому, розглядаючи сутність поняття виробничого циклу, який вимірюється синхронністю часу, містить виробництво, планування асортименту i якості, зміни технологій та транспорту, зберігання й організацію збуту, в якості критерію організації виробництва варто застосовувати метод цілісності часу, мінімізуючи загальні витрати часу. У такому випадку основною ціллю підприємства $\epsilon$ організація роботи й узгодження інтересів постачальників та посередників. Як наслідок, показники організаційної діяльності впливають на мінімізацію додаткових витрат, підвищення стійкості виробництва та якості виробленої продукції. Цілісність часу виробництва визначає, що необхідну продукцію потрібно виробляти у потрібний час і в потрібній кількості та якості, що вимагає синхронного планування доставки продукції від виробника до споживача.[8].

Логістичне управління здійснюється на основі загальних принципів управління 3 урахуванням специфіки логістичної діяльності [9]. Серед принципів логістичного управління можна виділити такі:

- системність і комплексність, які полягають в управлінні всіма потоковими процесами взаємодії та узгодженні окремих етапів бізнес-процесів 3 метою оптимізації всієї логістичної системи;

- узгодження критеріїв оцінки ефективності функціонування окремих ланок логістичного ланцюга на мікро- $\mathrm{i}$ макрологістичному рівнях;

- організацію обліку витрат на управління матеріальними й пов'язаними 3 ними інформаційними, фінансовими та сервісними потоками вздовж усього логістичного ланцюга;

- активніше використання інформаційних технологій та сучасних методів моделювання в управлінні логістичними системами та ін. 
Ефективна діяльність підприємства неможлива без упровадження інформаційної системи управління, наявність якої дозволяе швидше реагувати на зміни ринку, раціоналізувати управлінський процес, автоматизувати здійснення ряду операцій.

Основними

концептуальними положеннями логістичного підходу до управління внутрішньовиробничими потоками промислового підприємства $\epsilon$ сучасні тенденції в галузі управління потоками сировини та матеріалів, що передбачають перехід до гнучких планів виробництва, обміну та споживання [10]. Наявність гнучких планів дозволяє уникнути проблем, пов'язаних із використанням традиційних методів управління внутрішньовиробничими потоками промислового підприємства. Перш за все стає можливим складання більш збалансованих та внутрішньо узгоджених планів управління виробничими потоками й виробничогосподарською діяльністю промислового підприємства. Крім того, до таких планів значно легше і простіше вносити необхідні корективи.

Висновки: Таким чином, використання логістики в господарській діяльності ринкових структур в умовах реформування економіки України не може обмежитися лише раціоналізацією їх систем управління, а повинна супроводжуватися паралельним перетворенням їх у системи. У результаті ефект від iї використання набагато перевищить додаткову вигоду суб'єктів господарювання від раціональної (оптимальної) організації управління їх потоковими процесами. Розгляд потенціалу логістики та iï складників обумовлено потребою розробки механізму оцінки можливості застосування сучасних економічних підходів в практичній діяльності підприємства. Оцінка іiі потенціалу дасть змогу виявити приховані резерви в розвитку підприємства, а отже збільшити віддачу від більш обгрунтованого застосування сучасних економічних інструментів, підвищити ефективність логістичних процесів та отримати такий економічний ефект, як скорочення витрат i часу y сферах виробництва та обігу.

\section{ПЕРЕЛІК ВИКОРИСТАНИХ ДЖЕРЕЛ}

1.Науменко

M.O.

Маркетинг: навчальний посібник/ М. О. Науменко, В. І. Пеньков, Б. А. Рудов, Н. Г. Гончаренко. - Х.: АВВМВСУ, 2010. - 232 c.

2.Соколовський С.А. Управління якістю виробництва та обслуговування: навчальний посібник / С.А.Соколовський, С.П. Павлов,

М.В. Черкашина М.О. Науменко, С.М.Граб овський. - Харків: НАНГУ, - 2015. - 264c.

3.Устенко М.О Основні проблеми транспортної логістики» / M.О. Устенко/Вісник економіки транспорту i промисловості: збірник наукових праць. Харків, УкрДАЗТ, - 2010. - № 29. - С. 236238

4.Дикань В.Л. Актуальность улучшения системы комбинированных перевозок в международной транспортной сети // Вісник економіки транспорту i промисловості: Зб. наук. праць. - Харків: УкрДАЗТ, 2006. - № 13. - С. 13-20.

5.Науменко М.О. Основи економічної теорії: навчальний посібник./ М.О. Науменко, Б.А. Рудов, Л.В. Морозова. - X.: ABBMBCУ, 2012. = $340 \mathrm{c}$

6.Науменко М.О. Управління розвитком кластерно-мережних структур /М.О. Науменко// «Бізнес Інформ» ХНСУ, 2015. - Випуск № 3. - С. 269 - 275.

$$
\text { 7.Науменко М.О. Розробка }
$$
моделей стратегічного управління інтегрованими корпоративними структурами/ M.O. Науменко/ / Science Rise. - 2017. - № 3 (32). - C. 25-28.

8. Науменко М.О. Удосконалення організаційної та фанкціональної структури логістичного забезпечення Збройних сил України / М.О. Науменко, 
Л.В. Морозова/ «Бізнес Інформ» ХНСУ, 2016. - Випуск № 3. - С. 269 - 275.

9. Каличева Н.Є. Роль транспортно-логістичних систем $\mathrm{y}$ забезпеченні стійкого розвитку економіки [/Н.С. Каличева// Вісник економіки транспорту i промисловості: збірник наукових праць. - Харків, УкрДУзТ, 2017.

- № 58 . -C. 103-109.

DOI 10.18664/338.47:338.45.v\%vi\%i.133970
10. Каличева Н.Є. Логістичні підходи, як основа раціональної організації виробничого процесу на підприємстві/ Н.Є. Каличева , В.О. Маслова// Вісник економіки транспорту і промисловості: збірник наукових праць. - Харків, УкрДАЗТ, 2014. - № 47. - С. 83 - 86.

\title{
УДК 338:12.1
}

\section{СТРАТЕГІЧНЕ УПРАВЛІННЯ ПРОЦЕСОМ ЗАБЕЗПЕЧЕННЯ ЕФЕКТИВНОСТІ КОМЕРЦЙННӦ̈ ДІЯЛЬНОСТІ ПІДПРИЄМСТВА}

\author{
Черкашина М.В., к.е.н., доцент (НА НГУ)
}

В статті досліджено питання аналізу прочесу забезпечення ефективності комериійної діяльності підприємств в сучасних умовах. Проведення такого аналізу дозволило дослідити основні стратегічні орієнтири організації бізнесу в постіндустріальній економічі. Встановлено взаємозв'язок факторів ефективності управління та управлінських задач. Визначено, щзо в основі забезпечення й підвищення ефективності комериійної діяльності підприємств лежить також прочес побудови тісних інновачійно-виробничих зв'язків із суб'єктами ринкового середовища. зв'язки.

Ключові слова: стратегія, управління, процес, ефективність, підприємство,

\section{СТРАТЕГИЧЕСКОЕ УПРАВЛЕНИЕ ПРОЦЕССОМ ОБЕСПЕЧЕНИЯ ЭФФЕКТИВНОСТИ КОММЕРЧЕСКОЙ ДЕЯТЕЛЬНОСТИ ПРЕДПРИЯТИЯ}

Черкашина М.В., к.э.н., доцент (НА НГУ)

В статье исследованы вопросы анализа прочесса обеспечения эффективности коммерческой деятельности предприятий в современных условиях. Проведение такого анализа позволило исследовать основные стратегические ориентиры организации бизнеса в постиндустриальной экономике. Установлена взаимосвязь факторов эффрективности управления и управленческих задач. Определено, что в основе обеспечения и повышения эффективности коммерческой деятельности предприятий лежит также процесс построения тесных инновационно-производственных связей с субъектами рыночной средьл.

Ключевые слова: стратегия, управление, процесс, эффективность, предприятие, связи.

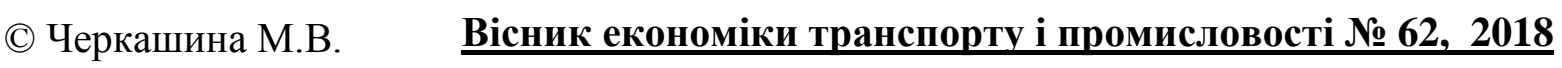

